\title{
INCREASING SCHOOL EFFECTIVENESS THROUGH PRINCIPALS' LEADERSHIP AND TEACHERS' TEACHING PERFORMANCE, IS IT POSSIBLE?
}

\author{
Heni Mulyani*, Danny Meirawan, Annisa Rahmadani \\ Universitas Pendidikan Indonesia, Indonesia \\ *e-mail: henimulyani@upi.edu
}

\begin{abstract}
Efforts to achieve educational goals cannot be separated from the performance of schools in realizing these goals, to achieve this involves many parties and factors that influence it. This study aims to describe the impact of principal's leadership and teacher's teaching performance in an effort to increase school effectiveness. This research uses a quantitative approach with a survey method. Proportionated stratified random sampling technique was used in this study. A total of 2,730 respondents comprising principals, teachers, students, and school committees participated in this study. The instrument used was a questionnaire. The main data analysis used in this study was the Structural Equation Model. The findings indicated that principals' leadership and teachers' teaching performance positively and significantly influenced school effectiveness, which means that school effectiveness was directly determined by the presence of effective principal's leadership and high teacher teaching performance. The principal's leadership as a driver variable was proven to be able to trigger the teaching performance of teachers to increase school effectiveness. The high effectiveness of this school was inseparable from the effective teacher's teaching performance. Teachers' teaching performance must be continuously improved to improve school effectiveness. This teaching performance can be improved through the principal's leadership role.
\end{abstract}

\section{Keywords: school effectiveness, principal leadership, teacher's teaching performance}

\section{PENINGKATAN EFEKTIVITAS SEKOLAH MELALUI KEPEMIMPINAN KEPALA SEKOLAH DAN KINERJA MENGAJAR GURU: MUNGKINKAH?}

\begin{abstract}
Abstrak: Upaya pencapaian tujuan pendidikan tidak terlepas dari kinerja sekolah dalam mewujudkan tujuan tersebut, untuk mencapai hal tersebut perlu melibatkan banyak pihak dan faktor yang memengaruhinya. Penelitian ini bertujuan untuk mendeskripsikan dampak kepemimpinan kepala sekolah dan kinerja mengajar guru dalam usaha peningkatan efektivitas sekolah. Penelitian ini menggunakan pendekatan kuantitatif dengan metode survei. Populasi 466 sekolah, sedangkan sampel sejumlah 210 sekolah yang diambil dengan teknik proportionated stratified random sampling, dan total responden 2.730 orang terdiri atas kepala sekolah, guru, siswa, dan komite sekolah. Instrumen yang digunakan adalah kuesioner dan telah memenuhi validitas dan reliabilitas. Teknik pengolahan data menggunakan Structural Equation Model. Hasil menunjukkan bahwa kepemimpinan kepala sekolah dan kinerja mengajar guru secara positif dan signifikan memengaruhi efektivitas sekolah. Hal itu berarti bahwa efektivitas sekolah secara langsung ditentukan oleh adanya kepemimpinan kepala sekolah yang efektif dan kinerja mengajar guru yang tinggi. Kepemimpinan kepala sekolah sebagai variabel pendorong terbukti mampu memicu kinerja mengajar guru untuk meningkatkan efektivitas sekolah. Efektivitas sekolah ini tidak dapat dipisahkan dari kinerja mengajar guru yang efektif. Kinerja mengajar guru harus terus ditingkatkan untuk meningkatkan efektivitas sekolah. Kinerja mengajar ini dapat ditingkatkan melalui peran kepemimpinan kepala sekolah.
\end{abstract}

Kata Kunci: efektivitas sekolah, kepemimpinan kepala sekolah, kinerja mengajar guru

\section{INTRODUCTION}

The problem of school effectiveness never end, because the effectiveness of schools is associated with school efforts to achieve their goals. In the process of achieving goals, it requires the efforts and roles of various parties and school officials. School effectiveness focuses on the efforts of schools in achieving the goals set 
through a systemic analysis or input, process, and output system approach as developed by Hoy \& Miskel (2008). As Yankey \& McClellan (2003) stated that organizational effectiveness is the extent to which the organization has been able to achieve the stated goals and objectives and how well its performance in the process. In the context of the interrelationship of educational inputs, processes, and outputs, the effectiveness aspect is one of the educational system performance groups that must be prioritized.

Therefore, school effectiveness is a prerequisite for improving the quality of education. School effectiveness shows the ability of schools to carry out their functions optimally to achieve the goals set, so to improve the quality of education the effectiveness of schools as educational institutions is needed, proven by many schools effectiveness research done by some previous researcher such as; Teddlie, Stringfield, \& Reynolds (2002); Teddlie, Creemers, Kyriakides, Muijs, \& Yu (2006); Uline, Miller, \& Tschannen-Moran (1998); Lunenburg (2010); Selamat, Samsu, \& Kamalu (2013) in various contexts. These researches were conducted to improve school effectiveness in various ways.

Studies in School Effectiveness Research (SER) have a profound impact on many fields, such as contextual sensitive studies have produced different results depending on the 'level' of the context variable being studied. Based on the theory put forward by Steers (1985) regarding organizational effectiveness, effectiveness in schools is not yet optimal as predicted due to the suboptimal implementation and optimization of the fulfillment of indicators that are prerequisites and determine the effectiveness of school organizations, including leadership of school principals and teacher teaching performance. The ideal conditions of effectiveness that must be achieved by each school are differ depending on the standards set by the country where the school is located. Achieving the ideal condition is inseparable from the factors that influence it.

Teddlie \& Stringfield (2007) identified that among the factors influencing school effectiveness were strong and effective principal's leadership and sustained focus on instruction and learning. In this previous study has not been focused on the teaching performance of teachers as those who carry out instruction and learning.
So it needs to be analyzed specifically how the influence of teacher teaching performance in increasing school effectiveness.

The success of education lies in the success of the principals and teachers' leadership in managing learning (Leithwood, Harris, \& Hopkins, 2008). Therefore, the principal as the leader of the education unit is required to be able to move all components and resources of the school to achieve effectiveness and effective learning by focusing on efforts to improve the quality of the process and learning outcomes. Tschannen-Moran (2009) explained that the principal's as the leader is responsible for micromanagement, which is directly related to the learning process in the school. The principal has formal authority to translate ideas and suggestions into school management. The principal can also act as a motivator to provide motivation and instill awareness to his subordinates about the importance of the quality of work results by prioritizing the implementation of tasks and responsibilities rather than their personal interests.

Lunenburg (2010) distinguishes between successful schools and effective schools. A successful headmaster will determine a successful school and an effective headmaster will determine an effective school. These differences appear in task dimensions, human resource activities, and behavioral profiles. In task dimensions, it can be seen how the principal's role in carrying out managerial tasks (creating and implementing policies, rules, procedures, and authority relations), also builds cultural linkages, which include the application of behavioral norms, using symbols, instituting rituals, and imaging to build the cultural foundations of school excellence.

Leadership in terms of the behavioral approach according to Dubrin (2010) has two aspects of leadership called Initiating Structure and Consideration. Initiating Structure leadership behavior according to Dubrin (2010) is the leadership behaviour of this structure is reflected in the behaviour of the leader who always organizes and defines relationships within the group by engaging in activities such as assigning specific tasks, determining procedures to be followed, scheduling work, and explaining expectations for team members. Leadership behaviour Consideration (tolerance) reflects the 
behaviour of leaders who pay attention to the needs of subordinates, always trying to create an atmosphere of mutual trust, trying to create an atmosphere of mutual respect, have a friendly attitude, foster participation in decision making and other activities, prioritizing self-direction, self-discipline, control yourself.

Leithwood et al. (2008) developed a transformational leadership model in schools. $\mathrm{He}$ mentioned, there are three categories of transformational leadership, namely: (1) direction setting, (2) developing people, and (3) redesigning the organization. Through these three leadership categories, the Principal Leadership Questionnaire (PLQ) was also developed which will be adapted in this study. Leadership behavior is reflected in the behavior of leaders who always organize and define relationships in groups by engaging in activities such as assigning specific tasks, determining procedures to be followed, scheduling work, and explaining expectations for members of the organization.

School effectiveness is also related to the teacher's teaching performance, because the teacher becomes an important factor in the creation of school effectiveness. Teachers must perform the best performance in carrying out their assignments and roles, both in the aspects of planning, implementing the learning process in class, as well as in assessing students by developing quality cultural values and developing quality, meaningful, and enjoyable learning for students. For this reason, teachers who have good performance are needed (Cheng, 2013).

Uline et al. (1998) states that there are two important dimensions of effective school namely instrumental functions and expressive functions. As Lezotte \& Snyder (2011) argued that effective schools cover various factors such as administrative functions including financing, leader behavior, morals, level of trust, culture and climate, parental involvement, community support, competencies, teacher performance, commitment, loyalty, and teacher satisfaction. In this case, an effective organization is a reflection of "the ability of an organization to mobilize its centers of power for action-production and adaptation". In this case, effective schools are characterized by the way they move their centers of strength, namely productivity, adaptability, and flexibility. These three characteristics are dimensions of school effectiveness that will be examined to strengthen theories and findings regarding the characteristics of effective schools.

Uline et al. (1998) stated that the teacher component in the effective school model, which includes the level of teacher confidence in schools, principals, and the existence of a healthy school climate can support teacher performance in achieving effective schooling. In this way, the capacity and performance of individual school residents, including school principals, administrators, teachers, and students, can be increased, accompanied by a strong emphasis on academic achievement and the expectations of students as well as parents of students.

The success of the principal in carrying out his leadership will have an impact on teacher's performance, as Lunenburg (2010) states that superior school principals (effective and successful) have teachers who are also superior. This is supported by effective communication from the principal to teachers. In addition, the school principal also manages human resources in such a way that they can motivate teachers and coordinate various teacher tasks. Teacher training and development coordinated by the principal and the principal's responsiveness to various teacher questions relating to the work of the teacher can improve various components of the school in achieving effective schooling.

Discussions about school effectiveness and the factors that influence it are always interesting because of the dynamic processes in schools in an effort to achieve their goals. Therefore this study aims to describe how to increase school effectiveness through the factors that influence it, namely the leadership of school principals and teacher teaching performance as the most dominant factors in increasing school effectiveness, by using dimensions on research variables that have not been examined in previous studies, these are (1) directing the environment (direction setting), directing people, and designing redesigning the organization as dimensions of principals' leadership; (2) focus on students and learning, learning content or materials, and learning practices as dimensions of teachers' teaching performance; and (3) service quantity, service quality, efficiency, adaptability, and flexibility as dimensions of school effectiveness. 


\section{METHODS}

This research uses a quantitative approach with a survey method. The subject was the Vocational High School in the field of business and management expertise spread in West Java province. The reasons for choosing West Java province was because West Java has the highest number of Vocational High Schools among other provinces in Indonesia. So that the population in this study was 466 Vocational High Schools consisting of 44 Vocational Public Schools and 422 Private Vocational Schools. To determine the number of samples, the proportionate stratified random sampling technique was used to distinguish between Public Vocational High Schools and Private Vocational High Schools, and to distinguish between schools accredited A, $\mathrm{B}$, and $\mathrm{C}$. So that the number of samples became 210 schools, with the total respondent 2.730 people consists of the school principal, teacher, student, and school committee.

The data collection technique used was a questionnaire with answer choices using a numerical scale with five choices. Research participants were asked to respond to statements on the most appropriate response choices regarding aspects of the principals leadership, teachers' teaching performance, and school effectiveness with responses ranging from 1 (lowest positive value) to 5 (highest positive value).

The school leadership questionnaire was adapted from the Principal Leadership Questionnaire (PLQ) which is developed by Leithwood \& Jantzi (2005). The teacher's teaching performance questionnaire was arranged according to CCSSO (2013) and International Schools Teacher Performance Evaluation system from AASA (2010). The school effectiveness questionnaire adapted Hoy's research questionnaire, the School Effectiveness Index. The questionnaire was tested through a reliability test and a validity test. The reliability calculation method used is the Cronbach Alpha formula. The instrument reliability criteria is $r_{l l}$ $>r_{\text {table }}$. The reliability of principal's leadership variable is $.89>.70$. The reliability of teacher's teaching performance variable is $.87>.70$. While the reliability for the school effectiveness variable is $.92>.70$. Meanwhile the formula used in the validity test is the Pearson Product Moment correlation coefficient formula, and all items on the instrument are declared valid because they meet the criteria $r_{\text {count }}>r_{\text {table. }}$.

The data analysis technique used in this research was structural equation model (SEM) analysis technique with Amos of 22.0 version software, in seven main steps as follows: (1) developing a theoretically based model, (2) constructing a path diagram of causal relationship, (3) converting the path diagram into a set of structural and measurement models, (4) choosing the input matrix type and estimating the proposed model, (5) assessing the identification of the structural model, (6) evaluating goodnessof-fit criteria, (7) interpreting and modifying the model. The reason for using this structural equation model is to explain the overall relationship between variables in the study. Description of the variables studied using descriptive statistical assistance seeks to present a summary of average achievement score data, percentages, and categories for each indicator and dimension of the research variable. The calculation formula refers to the opinion of Arikunto (2012), using the data range provisions $(r)=5.00-1.00$ (highest average score minus the lowest average score), and many criteria $(k)=5$, a class length $(p)=r / k=4 / 5=.8$. A clearer explanation of the average score criteria is presented in Table 1 .

\section{Table 1. Average Score Criteria}

\begin{tabular}{cc}
\hline Average Score & Category \\
\hline $1.00-1.80$ & Very low \\
$1.81-2.60$ & Low \\
$2.61-3.40$ & Fair \\
$3.41-4.20$ & High \\
$4.21-5.00$ & Very high \\
\hline
\end{tabular}

\section{RESULTS AND DISCUSSION Results}

The Principal Leadership variable $\left(X_{l}\right)$ consists of three dimensions, each has certain indicators that can be measured, namely dimensions: (1) directing the environment (direction setting), (2) directing people, and (3) designing redesigning the organization. In total there are 22 items for this variable. Respondents' responses to variable $X_{1}$ based on the average achievement value, percentage, and category can be presented in Table 2 . 
Table 2. Average Achievements, Percentages, and Categories each Dimension of the Principal Leadership Variable

\begin{tabular}{lcc}
\hline \multicolumn{1}{c}{ Dimension } & Average & Category \\
\hline Directing the environment & 3.83 & High \\
Directing people & 3.68 & High \\
Designing redesigning the organization & 3.86 & High \\
Principal leadership $\left(X_{I}\right)$ & 3.79 & High \\
\hline
\end{tabular}

The principal leadership variable was highly perceived by respondents. In other words, the leadership of school principals Vocational High Schools in was considered effective. Referring to the criteria for the average achievement score, the principal leadership variable is in the high category. The three dimensions used to measure school leadership, based on respondents' responses, the dimension of redesigning the organization $\left(X_{1.3}\right)$ is rated as the most prominent relative dimension compared to other dimensions on the principal leadership variable.

The three dimensions of principal's leadership are in the high category, this means that the principal's leadership of the Vocational School of Business and Management expertise in the Province of West Java in carrying out their duties and functions as a leader has carried out three main leadership activities namely directing the environment, directing people, and redesigning the organization.

Teacher' teaching performance variable $\left(X_{2}\right)$ consists of three dimensions, each of which has certain indicators that can be measured, namely dimensions: (1) focus on students and learning, (2) learning content or materials, and (3) learning practices. In total there are 19 items for this variable. Respondents to the variable $X_{2}$ based on the average achievement value, percentage, and category can be presented in Table 3.

The teacher's teaching performance variable was highly perceived by respondents. In other words, the teaching performance of teachers in Vocational High Schools is already considered high. This can be seen from the achievement of the average score of 3.97 (from the interval of 1.00 - 5.00). Referring to the criteria for the average achievement score, the variable teacher's teaching performance is included in the high category.
Based on respondent responses, the learning practices dimension $\left(X_{2,3}\right)$ was rated as the most prominent relative dimension compared to other dimensions on the teacher's teaching performance variable.

The school effectiveness variable $(Y)$ consists of five dimensions, each of which has certain measurable indicators, namely dimensions: (1) service quantity, (2) service quality, (3) efficiency, (4) adaptability, and (5) flexibility. In total there are 26 items for this variable. Respondents to the variable $\mathrm{Y}$ based on the average achievement value, percentage, and category can be presented in Table 4 .

The school effectiveness variable was highly perceived by respondents. This can be seen from the achievement of the average score of 3.97 (from the interval of $1.00-5.00$ ). Referring to the criteria of the average achievement score, the school effectiveness variable is included in the high category. Based on respondent responses, the service quality dimension $\left(Y_{2}\right)$ is rated as the most prominent relative dimension compared to other dimensions on the school effectiveness variable.

Meanwhile, the results of hypothesis testing show the following results presented in Table 5.

Structural equation model calculation results can be summarized as shown in Figure 1. The first model in the structural equation is: $X_{2}=.123 X_{1}$; with $R^{2}=.496$ and $\varepsilon=.504$. The results of testing the first hypothesis indicate that principal leadership directly has an influence on teachers teaching performance. This means that the teacher's teaching performance is directly determined by the principal's leadership. Principal's leadership has a positive effect on teacher teaching performance, meaning that the better the principal's leadership, the higher the teacher's teaching performance. 
Table 3. Average Achievements, Percentages, and Categories each Dimension of the Teacher's Teaching Performance Variable

\begin{tabular}{lcc}
\hline \multicolumn{1}{c}{ Dimension } & Average & Category \\
\hline Focus on students and learning & 3.98 & High \\
Learning content/materials & 3.92 & High \\
Learning practices & 3.99 & High \\
Teacher's teaching performance $\left(X_{2}\right)$ & 3.97 & High \\
\hline
\end{tabular}

Table 4. Average Achievements, Percentages, and Categories each Dimension of School Effectiveness Variables

\begin{tabular}{lcc}
\hline \multicolumn{1}{c}{ Dimension } & Average & Category \\
\hline Service quantity & 3.67 & High \\
Service quality & 3.80 & High \\
Efficiency & 3.57 & High \\
Adaptability & 3.57 & High \\
Flexibility & 3.69 & High \\
School effectiveness $(Y)$ & 3.66 & High \\
\hline
\end{tabular}

Table 5. Hypothesis Testing Estimates

\begin{tabular}{|c|c|c|c|c|c|c|c|}
\hline \multicolumn{3}{|c|}{ Model } & \multirow{2}{*}{$\begin{array}{c}\text { Estimation } \\
.123\end{array}$} & \multirow{2}{*}{$\begin{array}{r}\text { S.E. } \\
.036\end{array}$} & \multirow{2}{*}{$\begin{array}{c}\begin{array}{c}\text { C.R. } \\
(t \text {-test })\end{array} \\
2.589\end{array}$} & \multirow{2}{*}{$\begin{array}{c}p \text {-value } \\
.010^{*}\end{array}$} & \multirow{2}{*}{$\begin{array}{c}\begin{array}{c}\text { Significance } \\
\text { (acceptence) }\end{array} \\
\text { Significant (accepted) }\end{array}$} \\
\hline$X_{1}$ & $\rightarrow$ & $X_{2}$ & & & & & \\
\hline$X_{1}$ & $\rightarrow$ & $Y$ & .261 & .019 & 6.490 & .000 & Significant (accepted) \\
\hline$X_{2}$ & $\rightarrow$ & $Y$ & .147 & .019 & 5.022 & .000 & Significant (accepted) \\
\hline \multicolumn{3}{|c|}{$X_{1} \rightarrow X_{2}$} & \multicolumn{3}{|c|}{$R^{2}=.496 ; \varepsilon=.504$} & & Significant (accepted) \\
\hline \multicolumn{3}{|c|}{ influence } & \multicolumn{4}{|c|}{ Total $X_{1} \rightarrow X_{2}=.610$} & \\
\hline \multicolumn{3}{|c|}{$\begin{array}{l}X_{1}, X_{2} \rightarrow Y \\
\text { (simultaneous) }\end{array}$} & \multicolumn{2}{|c|}{$R^{2}=.684 ; \varepsilon=.316$} & & & Significant (accepted) \\
\hline
\end{tabular}

The second model in the structural equation is: $Y=.147 X_{2}+.261 X_{1}$ with $R^{2}=$ .684 and $\varepsilon=.316$. The results of the second hypothesis testing show that the principal's leadership variable $\left(X_{I}\right.$ and teachers teaching performance $\left(X_{2}\right)$ directly influence the school effectiveness $(Y)$. Principal's leadership, and teachers teaching performance significantly influences School Effectiveness. This means that school effectiveness is directly determined by the existence of effective principal's leadership, and high teachers teaching performance. Both of these $X$ variables have a positive effect on the $Y$ variable, meaning that the more effective the leadership of the principal $\left(X_{1}\right)$, the higher the effectiveness of the school $(Y)$. And the higher the teacher's teaching performance $\left(X_{2}\right)$, the higher the school's effectiveness $(Y)$. So to increase the effectiveness of schools can be done through the principal's leadership and teacher's teaching performance.

\section{Discussion}

Based on hypothesis testing, it is known that the principal's leadership has direct influence on teachers' teaching performance is relatively small. And school effectiveness is directly affected by the principal's leadership and teacher's teaching performance. Principal's leadership is proven to be determined by its dimensions namely directing the environment, directing people, designing redesigning the organization. The teachers' teaching performance is determined by its dimensions, how the teacher 


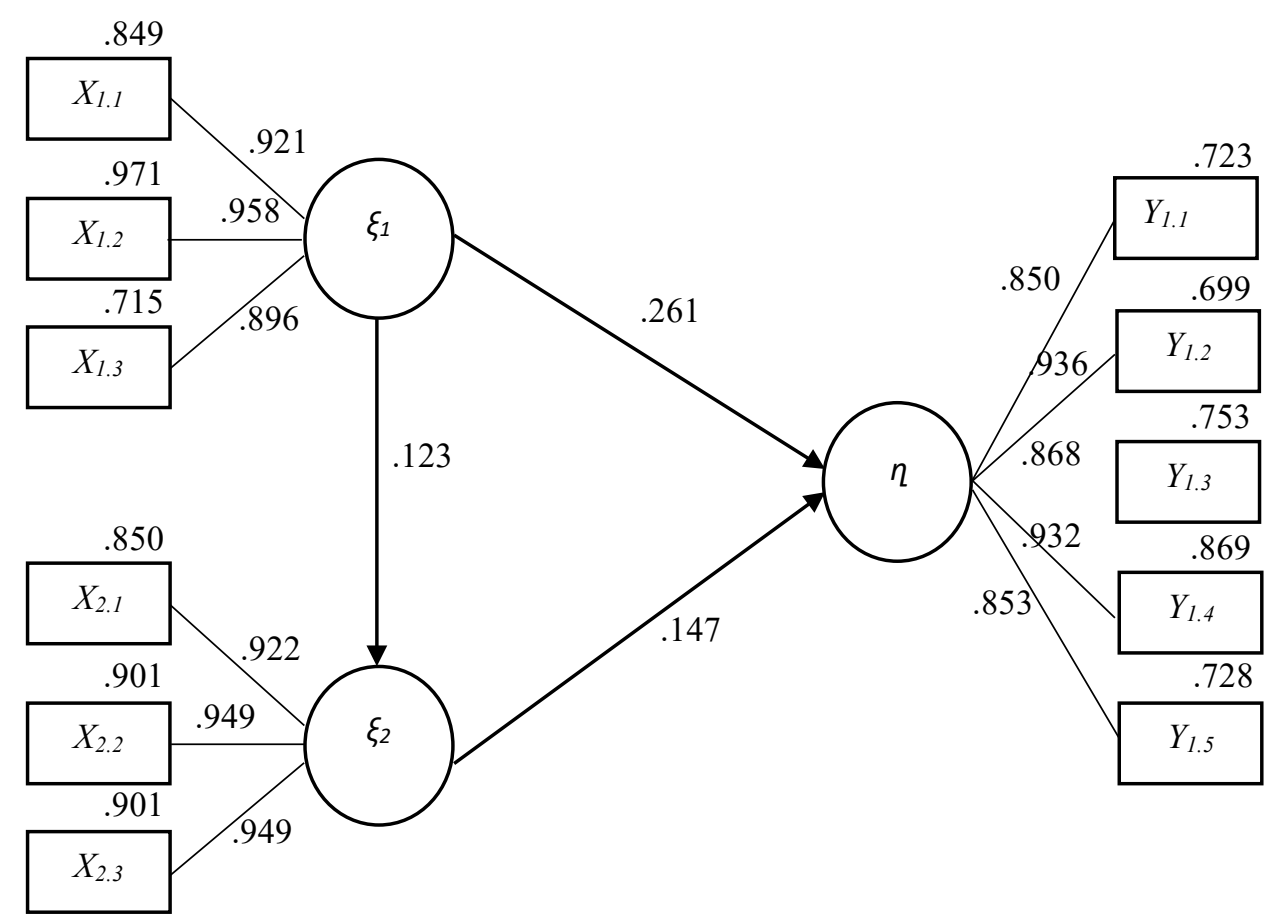

Figure 1. Structural Equation Model Calculation Results

manages learning that focuses on students and learning, designs learning content or materials, and implements learning practices. Likewise, school effectiveness is proven to be supported by the quantity of services provided by schools, the quality of their services, efficiency, adaptability, and flexibility.

Empirically, the principal's leadership variable as a driver variable is proven to be able to trigger a process variable that is the teaching performance of the teacher in improving school effectiveness. The high effectiveness of these schools is inseparable from the teaching performance of effective vocational high schools. The teaching performance of these teachers is strongly supported by the development of good human resources (educators and teaching staff), which is a development that can considerably impact school effectiveness. The high interaction between the principal's leadership and human resource development in turn greatly triggers effective teaching performance. The implication is that school effectiveness is high. In other words, the principal's leadership should be maintained and continuously improved so that in turn it can directly or indirectly increase school effectiveness. As Huber \& Mujis (2010) stated that the principals' leadership has long been seen as a key factor determining school effectiveness. Likewise Leithwood, Jantzi, \& Steinbach
(1999) argues that leadership is an important factor in supporting the achievement of school organization goals because the leadership of the school principal is a trigger that drives all components and activities in the organization.

The dimension directing the environment (direction setting) on the principal leadership variable is highly valued in shaping and reflecting effective headmaster's leadership. This can be seen from the efforts to identify and articulate a vision and provide an appropriate model. In this case, the principal is considered to have the ability to overcome obstacles that arise in achieving school goals. The principal also often gives instructions and orders politely. The principal is considered to be able to foster a belief that working together as a team will get better results. On top of that, the principal is believed to have the capability of making teachers feel and act as leaders. The principal often makes all teachers feel the purpose of his leadership role. In this case, the principal symbolizes success in the education profession. The school principal is also seen to be an example by giving good examples to school residents. In order to direct the environment better, the principal and the teachers have been able to formulate school goals using a problem-solving approach. In essence, principals are judged to behave in wise ways. As Horng, Klasik, \& Loeb (2010) concluded 
that the principals have quite complex work, so that it requires sufficient time to spend in school, to carry out, coordinate, and supervise various types of school activities and results, including student achievement and teacher performance assessment.

The directing people dimension on the principal's leadership variable is also highly valued in shaping and reflecting effective headmaster leadership. It is shown from the efforts to encourage acceptance of shared goals and efforts to provide individual support. In this case, the principal is considered to have included teacher participation in the process of developing school goals and has also encouraged teachers to work to achieve the same goals. In addition, school principals are judged to be able to work through the agreement of all school members in setting priorities for school goals, encouraging teachers to evaluate progress in achieving school goals, and providing training to develop relevant knowledge and skills for teachers. The principal is considered capable of treating each person as an individual who has different needs and expertise. When taking actions that will affect the work of the teacher, the principal also often considers the opinions of the teacher. In turn, the principal is expected to be able to motivate teachers to always make the school goals as the basis for carrying out work in school.

The redesigning the organization dimension on the principal's leadership variable is highly valued in shaping and reflecting effective principal's leadership. This can be seen from the efforts to provide intellectual stimulation and hold expectations for high performance. In this case, the principal is considered to be able to stimulate the teacher to think about what the teacher is doing for the benefit of students. The principal is also considered to be able to provide information on how to implement school programs. In addition, the principal has demanded the best performance from the school community, and the school principal shows the teacher that there are high expectations of the teacher as a professional. As Stupak (2008) in his research results that the function of a leader is to create an atmosphere and climate in which members of the organization can develop thereby increasing performance.

However, in some cases, principals have not been able to fully encourage teachers to evaluate progress in achieving school goals. The principal also has not been able to fully provide adequate training to develop relevant knowledge and skills for teachers. All this show that effective principal's leadership will largely determine how to improve teacher's teaching performance, and ultimately improve overall school effectiveness.

With an effective principal's leadership, it is predicted that a teachers' teaching performance will increase, and school effectiveness will, in turn, be achieved. This is in line with the results of Shen, Leslie, Spybrook, \& Ma (2012) research, principals can develop a collaborative culture and climate and a supportive structure that facilitates the main task of the teacher in the teaching and learning process. The principal's support can be a motivator for teachers to increase job satisfaction.

School principals are leaders of education who must be able to manage and distribute tasks to their subordinates (teachers and school staff) in order to successfully achieve school goals, as expressed by Soetopo (2010) how important and difficult is the position of the principal as an education leader. He must be able to distribute tasks to subordinates and be the first person to take responsibility for the success of the school in achieving its goals.

Principal's leadership is a trigger or driver that drives all components in the school so that it can realize the implementation and achievement of predetermined goals effectively. Hence that the success of a school principal's leadership will be reflected in the success of the school he leads, as according to Northouse (2018) which states that successful leaders are those whose organizations have succeeded in achieving goals.

As the findings in this study, that the principal's leadership directly influences the effectiveness of the school. To improve school effectiveness, the principal through his leadership can improve teacher's teaching performance. In line with the opinion expressed by Mulyasa (2002) that effective school principals are school principals who are: (1) able to empower teachers to carry out the learning process well, smoothly and productively; (2) can complete tasks and work in accordance with a predetermined time; (3) able to establish harmonious relations with the community so that they can actively involve them in realizing the goals of school and education; (4) successfully applies leadership principles in 
accordance with the level of maturity of teachers and other employees in the school; (5) work with a management team; (6) succeed in realizing the goals of the school productively in accordance with the stipulated provisions.

From the findings of this research, it is evident that the principal must have the ability to direct the environment, direct the people, and redesign the organization, so as to create a conducive school environment, with the creation of a conducive environment that can trigger teacher performance to improve and be better. As stated by Uben \& Hughes (1992) that the influence of the principal's leadership on teacher performance is in the form of creating a school climate that can spur or inhibit the effectiveness of teacher work.

In theory and practice, the development of organizational members (educators and education staff) is basically the responsibility of the leader (the principal). The principal as the leader of the school organization must naturally develop the quality of human resources owned by the school to be able to continue to respond to various challenges that exist in the world of education. In line with what Spencer \& Spencer (1993) state that organizational leaders should be able to develop others, guide support, direct, mobilize, and manage conflict. In the school environment, the principal directs, supervises, and provides support for the development of human resources for educators and education personnel in relation to education and training and career development.

These findings reinforce the principal's strategic role as the key person in the school (Danim, 2007). A principal who focus their relationships, their work, and their learning on the core business of teaching and learning are closely related to effective teaching and effective teacher learning (Robinson, Lloyd, \& Rowe, 2008). This means that the principal is the main actor as well as the person in charge of all activities carried out at the school. Therefore, effective headmaster's leadership is a must for quality school activities.

The results of hypothesis testing show that the direct effect of teacher's teaching performance on school effectiveness is statistically significant, with a path coefficient of .147 and a t-test of 5.022. The results of these calculations indicate that teacher teaching performance is an important component in determining school effectiveness. In this case, the teacher,s teaching performance does not stand alone because the teacher's teaching performance itself is influenced by the presence of the principal's leadership component.

The component of teacher's teaching performance consists of three dimensions, namely: (1) focus on students and learning, (2) content or learning materials, and (3) learning practices. Dimensions of focus on students and learning on the variable teacher's teaching performance is highly valued by the indicators of student development, differences in student learning, and the learning environment. In this case, the teacher is routinely able to assess student achievement to design teaching in meeting student learning needs. The teacher has also carried out learning by paying attention to the development of student learning. In addition, teachers are perceived to be able to design learning based on differences in student characteristics.

Teachers are also perceived to be able to access the resources needed to meet differences in learning and student learning needs. The focus on students and learning can also be seen from the high efforts of teachers in creating a positive learning climate, open and mutual respect. This can also be seen from the high efforts of teachers to use various relevant methods to involve students in learning. This shows the professionalism of teachers in an effort to improve school effectiveness, as Vinitwatanakhun (2002) argues that one measure of the effectiveness of professional development and quality of faculty.

The dimension of content or learning material on the teacher's teaching performance variable is also highly rated by the existence of subject matter knowledge indicators and application of subject matter. The teacher is considered to have been able to modify the teaching resources for the accuracy of the presentation of concepts in the subjects he teaches. The teacher is also considered capable of presenting material in accordance with the demands of student competence. In addition, teachers are considered to be able to use supporting resources and technology effectively to ensure access and relevance for all students. Finally, the teacher is considered to be able to involve students in applying knowledge to 
everyday problems through interdisciplinary themes. As Ball, Sleep, Boerst, \& Bass (2009) stated that learning materials and ways of working are supported by a collection of resources for the systematic improvement of the knowledge base for teachers.

The dimension of learning practices on the teachers teaching performance variable is also highly valued by the existence of indicators of learning planning, learning implementation, learning assessment, and follow-up learning. In this case, the teacher is considered to be able to use the applicable curriculum to prepare lesson plans. The teacher is also considered to have tried to practice various methods in learning and to try to use learning media. In addition, teachers are considered to have been able to use a variety of strategies that are appropriate for implementing teaching in accordance with student needs. The teacher has also used a variety of appropriate resources to implement teaching according to students' needs. In this case, the teacher has acted as a facilitator in learning, not just as a primary source of learning. The teacher is able to assess student learning outcomes, and the results of the assessment are checked and returned to students. Basically, teachers are considered capable of providing follow-up to students according to the results of the assessment.

From the results of this study, it can be stated that teacher's teaching performance will directly affect school effectiveness because teacher teaching performance is the core of the learning process as the main characteristic of school effectiveness. Teacher's teaching performance is a very important factor in student learning processes, teachers play a fundamental and dynamic role in the education system. So that it can be said that student learning achievement depends on the effectiveness of teaching the teacher. Factors that can affect teacher's teaching performance include school principal leadership, as stated by Adeyemi (2010) the principals can encourage the effective performance of their teachers by identifying their needs and trying to meet them.

School effectiveness $(Y)$ is influenced by the principal's leadership and teacher's teaching performance by .684 or $68.4 \%$. In other words, the contribution of the principal's leadership and teacher's teaching performance to school effectiveness is $68.4 \%$ and the remaining $31.6 \%$ is influenced by other factors outside this study. This indicates that the effectiveness of schools in West Java Vocational Schools, in general, are influenced by effective principal leadership and high teacher teaching performance. This school effectiveness component consists of five dimensions, namely: (1) Service quantity, (2) Service quality, (3) Efficiency, (4) Adaptability, and (5) Flexibility.

The dimension of service quantity on the school effectiveness variable is considered high with the indicators of completeness of the learning plan and the availability of guidance service time to students outside of study hours. In this case, learning plans such as the syllabus and Learning implementation plan owned by teachers in schools are considered to be complete. Teachers are considered to have self-composed teaching materials. Students at the school are also considered to have received many academic guidance services outside of class hours from subject teachers.

In general, many schools have provided guidance services for students who have special problems and/or students with special needs, including career guidance, counseling guidance, and so on. School services should be value-added activities, as Ladd \& Walsh (2002) concluded that actions taken to add value to school effectiveness must be done carefully so as not to distort incentives and prevent good teachers and administrators from working in schools that serve the concentration of disadvantaged students

The dimensions of service quality in this school effectiveness variable are rated high by the existence of indicators of the quality of the learning plan and the adequacy or flexibility of the time of guidance service to students outside of school hours. This can be seen from the existence of the syllabus and learning implementation plan prepared by teachers in schools that have been adapted to the demands of the latest curriculum. Here, teachers are considered to have made adjustments to teaching materials every semester. Schools are also considered to have a special schedule for academic guidance services outside of class hours. Basically, students who have special problems and/or who have special needs are well served by the existing teacher.

The efficiency dimension of this school effectiveness variable is also considered high by 
the indicators of the efficient use of resources by teachers and the efficient use of funds by school leaders. In this case, teachers in schools are considered to have tried to use school resources efficiently. Teachers sometimes finance their own activities related to professional development. Principals generally have allocated school funds efficiently. In turn, teachers can submit funding needs for the procurement of learning materials/ media to the principal.

The dimension of adaptability in this school effectiveness variable is also considered to be high, with indicators of teacher readiness to face changes in professionalism demands, school leaders allocate funds to upgrade teacher abilities, learning resources are adjusted to the needs of curriculum changes, teachers have sufficient information about curriculum changes, and teachers have the ability to innovate learning according to curriculum demands. In this case, teachers are considered ready to face the changing demands of professionalism. The level of knowledge and understanding of teachers in schools towards the demands of qualifications and competencies are in accordance with the demands of the legislation.

The school principal has sought to allocate funds to make efforts to improve teacher competency in this school. The school principal is also considered to have provided enough financial support to teachers who will continue their studies to a higher level. Learning resources in schools have been adapted to the needs of the latest curriculum changes. The school principal is considered to have provided enough financial support to teachers who will take part in training related to curriculum changes. As TDT (2015) states that the importance of school leaders planning, developing and monitoring the effectiveness of the school as a professional learning through great teaching of teachers. The role of teachers in improving school effectiveness can be done through high performance, one of which is teaching performance. The teacher's teaching performance is very important in the effort to achieve school goals, because the achievement of school goals is inseparable from the implementation of the learning process.

Basically, teachers in schools already have adequate information about the latest curriculum. Most of the teachers have also participated in training related to the implementation of the latest curriculum. In turn, the teachers at the school already have the ability to innovate learning according to the demands of the latest curriculum. Teachers in schools also have adequate knowledge about the impact of curriculum changes on teacher assignments. As Utomo, Suminar, \& Hamidah (2019) argue that in education, the quality of the teacher really determines how effective and efficient the teaching and learning process.

School effectiveness is determined by the level of success of the factors that influence it, how to empower and manage existing educational resources independently and creatively by involving school residents and the community in making participatory decisions in order to improve the quality of education in their schools.

School Effectiveness in the perspective of quality education can generate the idea of effective if the schools: (1) has student input with potential in accordance with curriculum demands, (2) can provide quality learning services, (3) has school facilities that support effectiveness and the efficiency of teaching and learning activities, (4) has the ability to create a conducive school climate as a reflection of the principal's professional leadership performance. Thus, the effectiveness of schools can be realized if every component contained in the school system is functioning properly.

Empirically, this study found that the principal's leadership have a direct effect on teachers teaching performance, and the principal's leadership and teacher's teaching performance had a significant direct effect on school effectiveness. For this reason, efforts are needed to improve the quality of teachers, while these efforts are: collegiality interactions between teachers in schools, understanding cognitive processes in the learning process, mastery of subject knowledge structures, ownership of understanding and appreciation of values, beliefs and standards, teaching skills, knowledge of how students learn.

To achieve the effectiveness of the teachers' performance depends on various aspects of the principal's leadership behavior. Teacher behavior also plays a role in determining teaching performance. Without the role of the teacher, the education system will become crippled. The importance of improving teacher 
teaching performance requires identifying factors that influence teacher teaching performance.

Thus this study reinforces the results of previous studies on the factors that influence school effectiveness, especially the factors of principal's leadership and teacher's teaching performance. This research also enriches aspects that can be improved on the principal's leadership factors and teacher's teaching performance so that it can improve school effectiveness. That the leadership aspect of the principal can be improved through the ability of the principal in directing the environment, directing people, and designing redesigning the organization. And teacher teaching performance can be improved through the ability of teachers in aspects of focus on students and learning, designing learning content or materials, and learning practices. The teacher's ability to improve teaching performance is inseparable from the principal's leadership role.

\section{CONCLUSION}

This research proves that school effectiveness is positively influenced by the principal's leadership and teachers' teaching performance. School effectiveness will run optimally if supported by several factors, including the commitment of the school, especially the role of the principal in improving teacher teaching performance. In this case, the principal is the key person to bring the school into a center of excellence, in printing and developing human resources and other resources. Considering the principal's position is so strategic, the principal must have adequate leadership. The intended leadership is the mastery of knowledge, skills, values, and attitudes that are reflected in the habits of thinking and acting when carrying out their roles and functions as the principal. The second factor is the teachers' teaching performance which is the core of the learning process as the main characteristic of school effectiveness. Teachers' teaching performance is a very important factor in student learning processes, teachers play a fundamental and dynamic role in the education system.

\section{ACKNOWLEDGEMENT}

Acknowledgments and awards are given to those who have provided advice, assistance, and convenience.

\section{REFERENCES}

AASA (Association of American Schools in South America). (2010). Handbook on the OSAC/AASSA: Teacher performance evaluation system. US: Author.

Adeyemi, T. (2010). Organizational climate and teachers' job performance in primary schools in Ondo State, Nigeria: An analytical survey. Asian Journal of Information Technology, 7(4), 138-145. doi:ajit.2008.138.145.

Arikunto, S. (2012). Prosedur penelitian: Suatu pendekatan praktek. [Research procedure: A practical approach]. Jakarta: Rineka Cipta.

Ball, D. L., Sleep, L., Boerst, T. A., \& Bass, H. (2009). Combining the development of practice and the practice of development in teacher education. The Elementary School Journal, 109(5), 458-474. doi:10.4236/ jss.2017.55015.

CCSSO (Council of Chief State School Officers). (2013). InTASC Model core teaching standards and learning progressions for teachers 1.0. Washington, DC: Author.

Cheng, Y. C. (2013). School effectiveness and school-based management: A mechanism for development. Washington, DC: Falmer Press.

Danim, S. (2007). Visi baru manajemen sekolah: Dari unit birokrasi ke lembaga akademik. [The new vision of school management: From the bureaucracy unit to the academic institution]. Jakarta: Bumi Aksara.

Dubrin, A. (2010). Leadership. Jakarta: Prenada Media.

Horng, E. L., Klasik, D., \& Loeb, S. (2010). Principal's time use and school effectiveness. American journal of education, 116(4), 491-523. doi:10.1086/653625.

Hoy, W. K. (nd). School effectiveness index (SEIndex). https://www.waynekhoy.com/ school-effectiveness/.

Hoy, W. K. \& Miskel, C. G. (2008). Educational 
administration: Theory, research and practice. New York, NY: McGraw Hill.

Huber, S. G., \& Muijs, D. (2010). School leadership effectiveness: The growing insight in the importance of school leadership for the quality and development of schools and their pupils. In Huber, S. G. (Ed.). School leadership-international perspectives.Dordrecht, Netherlands: Springer, pp. 57-77. doi:10.1007/978-90481-3501-1.

Ladd, H. F., \& Walsh, R. P. (2002). Implementing value-added measures of school effectiveness: Getting the incentives right. Economics of Education review, 21(1), 1-17. doi:10.1016/S02727757(00)00039-X.

Leithwood, K., Jantzi, D., \& Steinbach, R. (1999). Changing leadership for changing times. Buckingham: Open University Press.

Leithwood, K., \& Jantzi, D. (2005). A Review of Transformational School Leadership Research 1996-2005. Leadership and Policy in Schools, 4(3), 177-199. doi. org/10.1080/15700760500244769

Leithwood, K., Harris, A., \& Hopkins, D. (2008). Seven strong claims about successful school leadership. School leadership and management, 28(1), 2742. doi:10.1080/13632430701800060.

Lezotte, L. W., \& Snyder, K. M. (2011). What effective schools do: Re-envisioning the correlates. Bloomington, Indiana: Solution Tree Press.

Lunenburg, F. C. (2010). The principal as instructional leader. National forum of educationalandsupervisionjournal,27(4), 1-7. https://schoolturnaroundsupport.org/.

Mulyasa. (2002). Manajemen Berbasis Sekolah. [School Based Management]. Bandung: PT Remaja Rosdakarya

Northouse, P. G. (2018). Leadership: Theory and practice. Los Angeles: Sage publications.

Robinson, V. M., Lloyd, C. A., \& Rowe, K. J.
(2008). The impact of leadership on student outcomes: An analysis of the differential effects of leadership types. Educational administration quarterly, 44(5), 635-674. doi:10.1177/0013161X08321509.

Selamat, N., Samsu, N. Z., \& Kamalu, N. S. M. (2013). The impact of organizational climate on teachers' job performance. Educational Research, 2(1), 1-12. doi:10.5838/erej.2013.21.06.

Shen, J., Leslie, J. M., Spybrook, J. K., \& Ma, X. . (2012). Are principal background and school processes related to teacher job satisfaction? A multilevel study using schools and staffing survey 2003-2004. American Educational Research Journal, 49(2), 200-230. doi: $10.3102 / 0002831211419949$.

Soetopo, H. (2010). Perilaku organisasi. [Organizational Behavior]. Jakarta: PT Remaja Rosdakarya.

Spencer, M. L., \& Spencer, M. S. (1993). Competence at work: Models for superior performance. New York, NY: John Wiley \& Son, Inc.

Steers, R. (1985). Organizational effectiveness. New York, NY: McGraw Hill.

Stupak, R. J. (2008). Symposium on the future of public administration: Assumptions, processes, and projections part I. International Journal of Organization Theory \& Behavior, 11(3), 316-325. https://www.emerald.com/.

TDT (Teacher Development Trust). (2015). Developing great teaching: Lessons from the international reviews into effective professional development. London: Author.

Teddlie, C., Stringfield, S., \& Reynolds, D. (2002). Context issues within school effectiveness research. In C. Teddlie \& D. Reynolds (Ed.). The international handbook of school effectiveness research. New York, NY: Routledge, pp. 174-200.

Teddlie, C. \& Stringfield, S. (2007). A history 
of school effectiveness and improvement research in the USA focusing on the past quarter century. In T. Townsend (Ed.). International handbook of school effectiveness and improvement. Dordrecht, Netherlands: Springer, pp. 131-166. doi:10.1007/978-1-4020-5747-2.

Teddlie, C., Creemers, B., Kyriakides, L., Muijs, D., \& Yu, F. (2006). The international system for teacher observation and feedback: Evolution of an international study of teacher effectiveness constructs. Educational research and evaluation, 12(6), 561-582. doi:10.1080/13803610600874067.

Tschannen-Moran, M. (2009). Fostering teacher professionalism in schools: The role of leadership orientation and trust. Educational Administration Quarterly, 45(2), 217-247. doi:10.1177/0013161X08330501.

Uben, G. C. \& Hughes, L. W. (1992). The principal: Creative leadershipfor effective school. Boston, MA: Allyn and Bacon. doi:10.1177/019263658707150024.

Uline, C. L., Miller, D. M., \& TschannenMoran, M. (1998). School effectiveness: The underlying dimensions. Educational Administration Quarterly, 34(4), 462-483. doi:10.1177/0013161X98034004002.

Utomo, H. B., Suminar, D. R., \& Hamidah, H. (2019). Capturing teaching motivation of teacher in the disadvantaged areas. Cakrawala Pendidikan, 38(3), 398410. doi:10.21831/cp.v38i3.26411.

Vinitwatanakhun, W. (Apr. 2002). Factors affecting organizational effectiveness of nursing institutes in Thailand. Au Journal of Technology, 5(4), 207-211. http://www. journal.au.edu/.

Yankey, J. A., \& McClellan, A. (2003). The nonprofit board's role in planning and evaluation. Washington, DC: BoardSource. 